\title{
ANALISIS EVALUASI PEMBELAJARAN PENDIDIKAN AGAMA ISLAM DI SMA NEGERI 1 RAMBATAN, TANAH DATAR
}

\author{
Zulfawan Syafí \\ Guru PAI SMA Negeri 1 Rambatan \\ zulfawan.syafri.89@gmail.com
}

\begin{abstract}
The purpose of the study was to describe the instructional process of Islamic Education subject in State High School 1 Rambatan. This research was qualitative. The subjects of the study was the Islamic education teachers that consist of 3 teachers. The instruments of data collection were observation and documentation. Data were analyzed by using matrix analysis or logic analysis Glaser and Strauss. The results showed that the instructional process of Islamic Education subject in State High School 1 Rambatan was good category by observation score 66,24.
\end{abstract}

Keywords: Evaluation, Instructional Process, Islamic Education Subject, High School, Rambatan.

\section{PENDAHULUAN}

Tujuan pendidikan nasional adalah untuk membangkan potensi peserta didik agar rnenjadi manusia yang beriman dan bertaqwa kepada Tuhan Yang Maha Esa, berakhlak mulia, sehat, berilmu, cakap, kreatif, mandiri, dan menjadi warga negara yang demokratis serta bertanggung jawab. (Permendikbud No. 104 Th. 2014) Di antara tujuan pendidikan nasional tersebut adalah mengembangkan potensi peserta didik agar rnenjadi manusia yang beriman dan bertaqwa kepada Tuhan Yang Maha Esa dan berakhlak mulia. Agar potensi peserta didik dapat berkembang sesuai dengan tujuan pendidikan nasional maka peserta didik pada setiap satuan pendidikan berhak mendapatkan pendidikan agama sesuai dengan agama yang dianutnya dan diajarkan oleh pendidik yang seagama.

Pendidikan di sekolah dilaksanakan sebagai salah satu upaya dalam meningkatkan penguasaan pengetahuan tentang ajaran agama. Pendidikan Agama Islam merupakan suatu mata pelajaran yang penting untuk diajarkan di setiap jenjang pendidikan. Pelaksanaan proses pembelajaran Pendidikan Agama Islam berorientasi pada pencapaian tujuan. Tujuan Pendidikan Agama Islam tersebut adalah sudah tertuang dalam standar kompetensi yaitu menumbuhkan dan meningkatkan keimanan, melalui pemberian 
dan pemupukan pengetahuan, penghayatan, pengamalan serta pengalaman peserta didik tentang agama Islam sehingga menjadi manusia muslim yang terus berkembang dalam hal keimanan, ketaqwaannya kepada Allah SWT serta berakhlak mulia dalam kehidupan pribadi, masyarakat, berbangsa dan bernegara, serta untuk dapat melanjutkan pada jenjang pendidikan yang lebih tinggi (Permendikbud No. 104 Th. 2014).

Untuk mewujudkan tujuan tersebut, para pengampu pendidikan agama Islam dituntut tidak hanya sekedar menguasai ajaran agama secara tekstual, tetapi juga secara konseptual. Para pengampu Pendidikan Agama Islam, harus membuktikan kemampuannya dengan menghindarkan proses pembelajaran yang semata-mata diarahkan pada pencapaian target kognitif, sebab aspek afektif dan psikomotorik merupakan penentu teraktualisasikannya ajaran-ajaran moral dan budi pekerti pada perilaku anak didik, sebagai calon ulama, calon pendidik dan orang tua masa yang akan datang.

Dalam konteks ini, para pengampu pendidikan Agama Islam di setiap jenjang pendidikan, dihadapkan pada tuntutan tanggung jawab yang sangat besar. Jabatannya memang untuk mencari nafkah sebagaimana juga profesi-profesi lain, tetapi keberadaannya di lingkari oleh tanggung jawab untuk mewujudkan tujuan pendidikan nasional yang sangat tegas menunjukkan sasaran moral, keterampilan dan kecerdasan. Salah satu tantangan masa depan yang terkait dengan perubahan sosial yang semakin cepat adalah menyangkut pergeseran nilai-nilai dalam masyarakat. Dalam kehidupan sosial rnasyarakat, pendidikan bukan hanya satu upaya yang melahirkan proses pembelajaran dengan maksud membawa manusia menjadi sosok yang profesional secara intelektual (intellectual oriented) melalui proses transfer of knowledge yang kental, tetapi proses tersebut juga bermuara pada upaya pembentukan masyarakat yang berwatak, beretika dan berestetika melalui transfer of values yang terkandung di dalamnya (Nahlawi, 1995).

Peserta didik seharusnya diarahkan menjadi satu kelompok manusia yang responsif terhadap perkembangan ilmu pengetahuan dan teknologi (IPTEK), namun tidak meniscayakan aspek normatif yang begitu jelas pula peranannya dalam menciptakan suatu model kehidupan sosial yang humanis dalam kehidupannya yang plural. Daradjat (1992) menyatakan hal itu sebagai perubahan sikap dan tingkah laku yang sesuai dengan petunjuk ajaran Islam dengan tujuan agar kepribadiannya mengantarkan dan membuat seseorang menjadi insan kamil. Lebih lanjut Daradjat (1992) mengatakan bahwa pembinaan nilai-nilai agama telah dimulai di rumah 
dan dapat diteruskan di sekolah. Dalam pembinaan tersebut tidak hanya dilakukan oleh guru agama saja tetapi juga guru-guru lainnya, dan untuk lebih memperkuat lagi disarankan agar nilai-nilai agama itu perlu diwujudkan dalam kurikulum, metode atau strategi belajar-mengajar.

Dengan demikian pendidikan itu merupakan usaha sadar untuk menyiapkan peserta didik melalui kegiatan bimbingan, pengajaran atau latihan agar menjadi baik dan lebih baik. Muhajir mengatakan bahwa pengertian baik dan lebih baik disini adalah mencakup etiket, conduct atau perilaku terpuji. Berpijak pada tujuan Pendidikan Islam maka suatu lembaga pendidikan dianggap berkualitas apabila ia mampu menghasilkan peserta didik yang berilmu amaliah dan beribadah ilmiah. Dengan kata lain dapat juga digambarkan bahwa pendidikan Islam merupakan corak atau model pendidikan yang mempu membentuk manusia yang unggul secara intelektual, kaya dalam amal, dan anggun dalam moral. Kualitas perserta didik pada suatu lembaga pendidikan tidak semata-mata diukur penguasaan ilmu yang diperolehnya di bangku sekolah, tetapi juga dapat dilihat dari seberapa jauh mereka telah mengamalkan nilai-nilai agama yang dipeluknya.

Tujuan mata pelajaran Pendidikan Agama Islam dapat dicapai melalui pelaksanaan proses pembelajaran yang diselenggarakan oleh guru yang memenuhi ketentuan sebagai seorang guru Pendidikan Agama Islam, yang lulus dari pendidikan Ilmu Agama Islam jurusan Pendidikan Agama Islam, memiliki akta mengajar dan telah diangkat menjadi staf pengajar. Selanjutnya seorang guru yang telah diangkat sebagai tenaga pengajar pada suatu jenjang sekolah diharuskan membuat rencana pembelajaran sebelum melaksanakan kegiatan pembelajaran di kelas (Usman, 2001).

Rencana pembelajaran sebagai suatu rencana tertulis yang dibuat guru sebelum melaksanakan kegiatan pembelajaran harus dibuat sedemikian rupa sehingga menggambarkan kegiatan apa yang akan dilaksanakan di kelas. Pada hakekatnya bila suatu pembelajaran direncanakan terlebih dahulu, maka tujuan pengajaran akan lebih tearah dan lebih mudah dicapai. Namun pengajar sudah menganggap pekerjaan rutin sehari-hari sehingga pembuatan program pembelajaran terabaikan dan hanya menggunakan program pembelajaran tahuntahun yang sudah lewat. Bahkan kadang guru dalam mengajar tidak lagi berpedoman pada rencana pembelajaran, melainkan berdasarkan buku paket. Dengan kata lain masih banyak guru-guru yang tidak membuat rencana pembelajaran. Idealnya setiap guru harus membuat dan menguasai komponenkomponen program pembelajaran, yaitu 
penguasaan materi, analisis materi pelajaran, program tahunan/semester, program satuan pelajaran dan rencana pengajaran.

Rencana pembelajaran yang telah dibuat selanjutnya diaplikasikan dalam proses pembelajaran yang merupakan inti dari kegiatan Pendidikan Agama Islam di sekolah, oleh sebab itu dalam pelaksanaan pembelajaran tersebut terjadi interaksi antara guru dengan siswa, siswa dengan guru, siswa dengan siswa dalam rangka mencapai tujuan pembelajaran yang telah ditetapkan pada program pembelajaran (Mukminan, 2006). Konsep tujuan pembelajaran menitikberatkan pada tingkah laku siswa atau perbuatan (performance) sebagai jenis output yang terdapat pada siswa, yang dapat diamati dan menunjukkan bahwa siswa tersebut telah melakukan kegiatan belajar. Perubahan tingkah laku siswa ini akan tergantung bagaimana terjadinya proses pembelajaran di kelas. Artinya seorang guru dituntut untuk menguasai dan menerapkan berbagai macam metode dan strategi pembelajaran, sehingga akan membangkitkan motovasi dan minat siswa dalam belajar. Dengan kata lain jika dalam proses pembelajaran seorang guru tidak bisa menyesuaikan antara metode dan materi maka mustahil akan tercapainya tujuan pembelajaran. Istilah strategi mencakup metode, pendekatan, pemilihan sumber-sumber (termasuk medianya), pengelompokan siswa dan pengukuran keberhasilan (Hamalik, 2003).

Uraian di atas, kemampuan melaksanakan proses pembelajaran merupakan sesuatu hal yang harus dimiliki oleh seorang guru Pendidikan Agama Islam. Sementara jika diamati, guru-guru Pendidikan Agama Islam di SMA masih memiliki kemampuan yang kurang dalam melaksanakan kegiatan proses pembelajaran di kelas, seperti yang terjadi di SMA Negeri 1 Rambatan. Dari pengamatan peneliti, guru PAI SMA Negeri 1 Rambatan masih menggunakan metode-metode mengajar yang kurang variatif, terkadang hanya menggunakan metode ceramah dan tugas, hal ini nantinya akan berpengaruh terhadap pencapaian tujuan pembelajaran PendidikanAgama Islam itu sendiri.

Tujuan pembelajaran yang telah ditetapkan dalam rencana pembelajaran akan mudah diketahui tingkat ketercapainnya lewat penilaian yang dilaksanakan guru selama berlangsung pembelajaran. Di samping itu dengan dilakukannya penilaian akan diketahui sejauh mana tingkat keberhasilan yang dicapai siswa. Oleh karena itu, kemampuan menilai sangat penting artinya bagi seorang guru. Data yang diperoleh dari hasil penilaian, diolah untuk menjadi sebuah informasi, dan selanjutnya informasi tersebut memberikan gambaran yang tepat mengenai hasil belajar siswa. 
Uraian tersebut menunjukkan, kemampuan dalam menilai proses pembelajaran merupakan sesuatu hal yang harus dimiliki oleh seorang guru Pendidikan Agama Islam. Dalam pengamatan peneliti, guru Pendidikan Agama Islam kurang berminat dalam melakukan penilaian baik di awal pembelajaran maupun selama proses berlangsungnya pembelajaran. Guru PAI lebih cenderung melakukan penilaian ketika di akhir pembelajaran saja. Padahal dengan melakukan tes di awal pembelajaran akan membantu guru untuk menentukan dari mana pembelajaran dimulai. Apabila melakukan penilaian selama berlangsungnya proses pembelajaran tentunya akan diketahui kemampuan dan kelemahan siswa dalam penguasaan pengetahuan dan keterampilan, sehingga dapat dilakukan perbaikan dan pengayaan. Memperhatikan permasalahan tersebut, kiranya perlu diadakan evaluasi terhadap proses pembelajaran Pendidikan Agama Islam, agar dapat diketahui gambaran sesungguhnya tentang pelaksanaan pembelajaran Pendidikan Agama Islam di SMA Negeri 1 Rambatan.

\section{PEMBELAJARAN PENDIDIKAN AGAMA ISLAM}

Pembelajaran merupakan upaya sadar dan sengaja oleh guru untuk membuat siswa belajar melalui pengaktifan berbagai unsur dinamis dalam proses belajar siswa. Pembelajaran adalah proses interaksi peserta didik dengan pendidik dan sumber belajar pada suatu lingkungan belajar. Menurut Hamalik (2003) pembelajaran itu merupakan suatu kombinasi yang tersusun dari unsur-unsur manusiawi, material, fasilitas, perlengkapan, dan prosedur yang saling mempengaruhi dalam mencapai tujuan. Manusia yang terlibat dalam sistem pembelajaran terdiri dari siswa, guru, dan tenaga lainnya misalnya tenaga laboratorium. Material meliputi buku-buku, papan tulis, dan kapur, fotografi, slide dan film, audio dan video tape. Fasilitas dan perlengkapan terdiri dari ruangan kelas, perlengkapan audio visual, dan komputer, sedangkan prosedur meliputi jadwal dan metode penyampaian informasi, praktik, belajar, ujian dan sebagainya.

Berdasarkan pengertian di atas pembelajaran merupakan perpaduan interaksi antara sumber belajar (guru, media, materi dan lain sebagainya) yang dapat mempengaruhi siswa dalam rangka mencapai tujuan pembelajaran yang telah ditetapkan. Dalam kontek berbeda namun mengandung makna yang sama dengan pembelajaran, Usman (2001) mengatakan babwa proses belajar mengajar merupakan suatu proses yang mengandung serangkaian perbuatan guru dan siswa atas dasar hubungan timbal 
balik yang berlangsung dalam situasi edukatif untuk mencapai tujuan tertentu. Interaksi atau hubungan timbal balik antara guru dan siswa itu merupakan syarat utama bagi berlangsungnya proses belajar mengajar. Interaksi dalam peristiwa belajar mengajar mempunyai arti yang lebih luas, tidak sekedar hubungan antara guru dengan siswa, tetapi berupa interaksi edukatif. Dalam hal ini bukan hanya penyampaian pesan berupa materi pelajaran, melainkan penanaman sikap dan nilai pada diri siswa yang sedang belajar.

Mohammad (1979) mengemukakan bahwa pendidikan Islam adalah proses mengubah tingkah laku individu pada kehidupan pribadi, masyarakat dan alam sekitamya dengan cara pengajaran sebagai aktivitas asasi, sebagai profesi asasi dalam masyarakat. Sedangkan Muhaimin dan Mujib (Hamalik, 1993) pendidikan Islam adalah suatu sistem pendidikan yang memungkinkan seseorang dapat mengarahkan kehidupannya sesuai denagn cita-cita Islam, sehingga dengan mudah ia membentuk hidupnya sesuai dengan ajaran Islam. Pengertian ini mengacu pada perkembangan kehidupan manusia masa depan, tanpa menghilangkan prinsip-prinsip Islam yang diamanatkan Allah SWT kepada manusia sehingga manusia mampu memenuhi kebutuhan dan tuntutan hidupnya, seiring dengan perkembangan ilmu pengetahuan dan teknologi. Pengertian pendidikan agama Islam menurut Mappanganro (1996: 10) yaitu usaha sadar yang berupa pengajaran, bimbingan dan asuhan terhadap anak agar kelas setelah selesai pendidikannya dapat memahami, menghayati dan mengamalkan ajaran agamanya serta menjadikannya sebagai way of life (jalan kehidupan) seharihari, baik dalam kehidupan pribadi maupun sosial kemasyarakatan.

\section{POLA PEMBELAJARAN PENDIDIKAN AGAMA ISLAM}

Dalam proses pembelajaran, dikenal berbagai pola pembelajaran yang menggambarkan kedudukan serta peran guru dan peserta didik dalam proses pembelajaran. Pada awalnya pola pembelajaran didominasi oleh guru sebagai satu-satunya sumber belajar, penentu metode belajar, bahkan termasuk penilai kemajuan belajar peserta didik. Namun seiring dengan perkembangan ilmu pengetahuan dan teknologi, pembelajaran terus mengalami perkembangan.

Kecenderungan pembelajaran dewasa ini adalah sistem belajar mandiri dalam program terstruktur. Untuk iru perlu dipersiapkan sumber yang memungkinkan dapat dipergunakan peserta didik secara langsung. Sumber belajar jenis ini lazimnya berupa media sehingga hasilnya dapat 
dimanfaatkan scbagai media pembelajaran. Guru berinteraksi dengan peserta didik berdasarkan suatu tanggung jawab bersama. Sejalan dengan meningkatnya kebutuhan akan kualitas tenaga guru yang profesional, salah satu jalan yang dapat ditempuh adalah membekali para guru agar mampu mengembangkan berbagai media dalam proses pembelajaran. Pengajar dapat mempersiapkan beban pelajaran yang sistematis dan terprogram seperti buku ajar, modul atau media lain yang dapat menunjang kegiatan pembelajaran. Dengan demikian pelajar akan lebih mandiri dalam melaksanakan kegiatan pembelajaran (Muhaimin, 2002).

\section{PENDEKATAN PEMBELAJARAN PAI}

Upaya dalam pencapaian peningkatan kemampuan siswa dalam bentuk keterampilan (psikomotorik), pengetahuan (kognitif) dan sikap (afektif) dapat melalui pendekatan pembelajaran yang digunakan oleh pendidik, beberapa pendekatan pembelajaran yang bisa digunakan dalam proses pembelajaran pendidikan agama Islam yaitu a) keimanan, memberikan peluang kepada peserta didik untuk mengembangkan pemahaman adanya Tuhan sebagai sumber kehidupan makhluk sejagat ini; b) pengalaman, memberikan kesempatan kepada peserta didik untuk mempraktikkan dan merasakan hasil-hasil pengamalan ibadah dan akhlak dalam menghadapi tugas-tugas dan masalah dalam kehidupan; c) pembiasaan, memberikan kesempatan kepada peserta didik untuk membiasakan sikap dan perilaku yang baik, sesuai dengan ajaran Islam dan budaya bangsa dalam menghadapi masalah kehidupan; d) rasional, usaha memberikan peranan pada rasio (akal) peserta didik dalam memahami dan membedakan berbagai bahan ajar dalam materi pokok serta kaitannya dengan perilaku yang baik dengan perilaku yang buruk dalam kehidupan duniawi; e) emosional, upaya menggugah perasaan (emosi) peserta didik dalam menghayati perilaku yang sesuai dengan ajaran agama dan budaya bangsa; $f$ ) fungsional, menyajikan bentuk semua materi pokok (al Qurlan, keimanan, ibdah/fiqih, akhlak dan tarikh) dari segi manfaatnya bagi peserta didik dalam kehidupan sehari-hari dalam arti luas; dan g) keteladanan, yaitu menjadikan figur guru agama dan non-agama serta petugas sekolah lainnya maupun orang tua, peserta didik, sebagai cermin manusia berkepribadian agama (Depdikbud, 2014).

\section{METODE PENELITIAN}

Jenis penelitian ini merupakan penelitian deskriptitf kualitatif yaitu penelitian tentang data yang dikumpulkan dan dinyatakan dalam bentuk kata-kata. Kata-kata disusun dalam kalimat, misalnya kalimat hasil 
observasi dan dokumentasi (Saebani: 2008). Penelitian ini menggunakan pendekatan kualitatif, berusaha mendapatkan informasi yang selengkap mungkin mengenai evaluasi pelaksanaan pembelajaran di SMA Negeri 1 Rambatan. Teknik pengumpulan data yang digunakan adalah dengan observasi, dan dokumentasi.

Observasi yang dilakukan oleh peneliti untuk mengetahui proses belajar mengajar di kelas di mana variabel yang diungkap didaftar, kemudian di Checklist kemunculannya dan jika perlu kualitas kejadian itu dijabarkan lebih lanjut. Analisis dokumen dilakukan untuk mengumpulkan data yang bersumber dari arsip dan dokumen baik yang berada di sekolah atau yang berada berada di luar sekolah, yang ada hubungannya dengan penelitian tersebut.

Tahap-tahap dalam pengumpulan data dalam penelitian ini, yaitu "tahap orientasi, tahap ekplorasi dan tahap member chek. Tahap orientasi, dalam tahap ini yang dilakukan peneliti adalah melakukan prasurvey ke lokasi yang diteliti, dalam penelitian ini, prasurvey dilakukan di SMA Negeri 1 Rambatan terhadap guru PAI. Kemudian peneliti juga melakukan studi dokumentasi serta kepustakaan untuk melihat dan mencatat data-data yang diperlukan dalam penelitian ini. Tahap eksplorasi, tahap ini merupakan tahap pengumpulan data di lokasi penelitian, dengan melakukan observasi tidak langsung tentang kondisi sekolah dan mengadakan pengamatan langsung tentang evaluasi pelaksanaan pembelajaran PAI di sekolah itu. Tahap checklist, setelah data diperoleh di lapangan, baik melalui observasi, ataupun studi dokumentasi, untuk melengkapi atau merevisi data yang baru, maka data yang ada tersebut diangkat dan dilakukan audit trail yaitu mencek keabsahan data sesuai dengan sumber aslinya” (Zariah: 2005).

Manurut Patton (2007), teknik analisis data adalah "proses kategori urutan data, mengorganisasikannya ke dalam suatu pola, kategori dan satuan uraian dasar, ia membedakannya dengan penafsiran yaitu memberikan arti yang signifikan terhadap analisis, menjelaskan pola uraian dan mencari hubungan di antara dimensidimensi uraian". Analisis dilakukan dengan pendekatan analisis matriks atau analisis logika. Analisis matriks yaitu analisis data dengan melihat garis besar sebab akibat secara umum, proses penalaran logis dan sebagainya. Biasanya pendekatan ini menggunakan diagram, bagan, tabel, dan sebagainya.

\section{HASIL PENELITIAN DAN PEMBAHASAN}

Model evaluasi yang digunakan dalam penelitian ini adalah evaluasi formatif yang 
dikembangkan oleh Scriven. Model ini dipilih mengingat tujuan penelitian ini yaitu untuk mengetahui bagaimana proses pembelajaran Pendidikan Agama Islam pada SMA Negeri 1 Rambatan. Sedangkan kriteria yang digunakan untuk mengevaluasi pelaksanaan proses pembelajaran PAI di SMA Negeri 1 Rambatan adalah sebagai berikut.

1. Mengerjakan Tugas Rutin dan Membuka Pelajaran

\begin{tabular}{|l|l|l|l|l|}
\hline 1. Mengerjakan tugas rutin & 1 & $\underline{2}$ & 3 & 4 \\
\hline 2. Membuka pelajaran & 1 & 2 & 3 & 4 \\
\hline
\end{tabular}

2. Melaksanakan Strategi Pembelajaran

\begin{tabular}{|l|l|l|l|l|}
\hline $\begin{array}{l}\text { 3. Melaksanakan strategi } \\
\text { pembelajaran dengan kegiatan } \\
\text { yang sesuai dengan tujuan, materi, } \\
\text { situasi, clan konteks }\end{array}$ & 1 & 2 & 3 & 4 \\
\hline $\begin{array}{l}\text { 4. Menggunakan alat bantu/media } \\
\text { pembelajaran }\end{array}$ & 1 & 2 & 3 & 4 \\
\hline $\begin{array}{l}\text { 5. Melaksanakan kegiatan } \\
\text { pembelajaran dalam urutan yang } \\
\text { logis }\end{array}$ & 1 & 2 & 3 & 4 \\
\hline $\begin{array}{c}\text { 6. Menggunakan waktu } \\
\text { pembelajaran secara efisien }\end{array}$ & 1 & 2 & 3 & 4 \\
\hline
\end{tabular}

3. Mendemonstrasikan Penguasaan Materi Pembelajaran

\begin{tabular}{|c|l|l|l|l|}
\hline $\begin{array}{c}\text { 1. Mendemonstrasikan penguasaan } \\
\text { materi pembelajaran }\end{array}$ & 1 & 2 & 3 & 4 \\
\hline
\end{tabular}

4. Mendorong Keterlibatan Siswa dalam Proses Pembelajaran dan Kemampuan Siswa untuk Belajar

\begin{tabular}{|l|l|l|l|l|}
\hline $\begin{array}{l}\text { 1. Memicu dan memelihara } \\
\text { keterlibatan siswa }\end{array}$ & 1 & 2 & 3 & 4 \\
\hline $\begin{array}{l}\text { 2. Mendorong terjadinya interaksi } \\
\text { antara guru dan siswa, siswa dan } \\
\text { siswa }\end{array}$ & 1 & 2 & 3 & 4 \\
\hline $\begin{array}{l}\text { 3. Meningkatkan kemampuan } \\
\text { berpikir tingkat tinggi }\end{array}$ & 1 & 2 & 3 & 4 \\
\hline
\end{tabular}

\begin{tabular}{|c|c|c|c|c|}
\hline $\begin{array}{l}\text { 4. Mengembangkan sikap mandiri } \\
\text { dan kemampuan belajar }\end{array}$ & 1 & 2 & 3 & 4 \\
\hline
\end{tabular}

5. Komunikasi Antar Pribadi

\begin{tabular}{|c|c|c|c|c|}
\hline $\begin{array}{c}\text { 1. Menunjukkan sikap terbuka dan } \\
\text { demokratis }\end{array}$ & 1 & 2 & 3 & 4 \\
\hline $\begin{array}{c}\text { 2. Mengembangkan hubungan antar } \\
\text { pribadi di dalam kelas }\end{array}$ & 1 & 2 & 3 & 4 \\
\hline
\end{tabular}

6. Melaksanakan Evaluasi Proses dan Basil Pembelajaran

\begin{tabular}{|l|l|l|l|l|}
\hline $\begin{array}{c}\text { 1. Melaksanakan penilaian selama } \\
\text { proses pembelajaran }\end{array}$ & 1 & 2 & 3 & 4 \\
\hline $\begin{array}{c}\text { 2. Melaksanakan penilaian setelah } \\
\text { proses pembelajaran }\end{array}$ & 1 & 2 & 3 & 4 \\
\hline
\end{tabular}

7. Menutup Pelajaran

\begin{tabular}{|l|c|c|c|c|}
\hline $\begin{array}{l}\text { 1. Membuat rangkuman materi } \\
\text { pembelajaran }\end{array}$ & 1 & 2 & 3 & 4 \\
\hline 2. Melaksanakan tindak lanjut & 1 & 2 & 3 & 4 \\
\hline
\end{tabular}

Adapun kriteria yang digunakan yaitu:

\begin{tabular}{|c|l|l|}
\hline POIN & KLASIFIKASI NILAI & \multicolumn{1}{|c|}{ KATEZORT } \\
\hline 1 & $76-100$ & Baik sekali \\
\hline 2 & $51-75$ & Baik \\
\hline 3 & $26-50$ & Kurang baik \\
\hline 4 & $0-25$ & Sangat kurang baik \\
\hline
\end{tabular}

Berdasarkan tabel di atas peneliti menilai untuk mengerjakan tugas rutin dan membuka pembelajaran oleh guru yaitu 74 dan 83 . Dalam menggunakan strategi pembelajaran, peneliti menilai guru sejumlah 73, 74, 65, dan 60. Dalam mendemontrasikan materi, peneliti menilai guru sejumlah 86 dan untuk mendorong siswa berpartisipasi aktif senilai 69, 71, 49, dan 48. Untuk komunikasi antar pribadi menurut peneliti guru mendapatkan nilai sejumlah 47, 48 dan pelaksanaan evaluasi senilai 35 dan 75 . Terakhir dalam menutup 
pembelajaran guru cukup baik dengan mendapat nilai 85 dan 84 . Rata-rata nilai evaluasi pelaksanaan proses pembelajran PAI di SMA Negeri 1 Rambatan yaitu 66,24 terkategori baik.

Jadi, dapat diketahui bahwa untuk mengerjakan tugas rutin membuka pelajaran, menggunakan metode dan media sesuai materi telah termasuk kategori baik, namun kurang baik pada pelaksanaan pembelajaran yang kurang logis dan penggunaan waktu secara efisien. Hal itu disebabkan karena guru sibuk memarahi siswa yang nakal dan tidak sistematisnya materi yang disampaikan. Pada demontrasi penguasaan materi dan menciptakan interaksi dan keaktifan siswa dalam pembelajaran guru sudah melakukannya dengan baik, namun tidak pada peningkatan pemikiran tingkat tinggi dan menciptakan kemandirian pada siswa. Hal itu disebabkan guru adakalanya sering mematahkan semangat siswa dan cukup puas saja dengan materi yang disampaikan.

Komunikasi antar pribadi di dalam kelas oleh guru masih tergolong kurang, begitu juga dengan evaluasi saat proses pembelajaran. $\mathrm{Hal}$ itu disebabkan guru masih tergolong pilih kasih pada sebagian siswa dan sibuk memarahi siswa yang nakal. Namun untuk menutup pembelajaran guru sudah tergolong baik karena pelajaran disimpulkan dan diberikan tindak lanjut berupa tugas.

\section{KESIMPULAN}

Berdasarkan uraian diatas kesimpulan penelitian ini adalah guru PAI telah melaksanakan evaluasi proses pembelajaran secara baik. Hal itu terbukti dengan hasil penelitian bahwa guru PAI mendapatkan nilai 66, 24 di mana nilai tersebut terletak pada interval 51-75 yang tergolong baik. Meskipun demikian butuh pembenahan pada peningkatan kemampuan peserta didik dan komunikasi antar pribadi di kelas.

\section{REFERENSI}

Daradjat, Zakiah. (1992). Ilmu Pendidikan Islam, Jakarta: Bumi Aksara.

Depdikbud. (2006). Kurikulum Pendidikan Agama Islam. Jakarta: Pusat Pengembangan Kurikulum.

Hamalik, Omar. (2003). Kurikulum dan Pembelajaran. Jakarta: Bumi Aksara, 2003. (2002). Perencanaan Pengajaran Berdasarkan Pendekatan Sistem. Jakarta: Bumi Aksara.

Mappanganro. (1996). Implementasi Pendidikan Islam di Sekolah, Ujung Pandang: CV. Berkat Utami.

Muhaimin. (2002). Paradigma Pendidikan Islam Upaya Mengefektifkan Pendidikan Agama Islam di Sekolah. Bandung: Rosdakarya. 
Muhaimin dan Mudjib. (1993). Pemikiran Pendidikan lslam. Jakarta: Tri Ganda Karya, 1993.

Mukminan. (2006). Desain Pembelajaran.

Yogyakarta: Universitas Negeri Yogyakarta.

Nahlawi, Abdurrahman. (1995). Pendidikan

Islam di Rumah, Sekolah dan Masyarakat.

Jakarta: Gema lnsani Press.
Omar, Muhammad. (1979). Falsafah Pendidikan Islam, Jakarta: Bulan Bintang.

Permendikbud No. 104 Tahun 2014.

Usman, Moh. Uzer. (2001). Menjadi Guru Profesional, Bandung: Rosdakarya. 